\title{
Self instillation perception of eye drops in elderly patients with and without facial support device
}

\author{
Percepção de autoinstilação de gotas oculares \\ em idosos com ou sem dispositivo de apoio facial
}

Arlindo Jose Freire Portes ${ }^{1}$, Ruan Machado Guilhon Lopes², Marcella Guimarães Cardoso², Rafael Abbud Fernandes², Thamara Abreu Souza ${ }^{2}$

\begin{abstract}
Objective: To determine the degree of difficulty for topical ocular instillation in the elderly, through a questionnaire, with or without the aid of facial support device. Observe which method was technically better to topical ocular application of drops. Methods: The study was a clinical trial, controlled, randomized and paired, which was conducted in 50 elderly patients from September 2015 to June 2016 at the Polyclinic Ronaldo Gazolla, Lapa, Rio de Janeiro. A Optive ${ }^{\circledR}$ eyedrop bottle was attached to a facial support device called Eyedrop ${ }^{\circledR}$. Each participant instilled an eye drop with or without the device help in each of both eyes, wherein the eye selection was made randomly. He was asked to answer pre-formulated questions about the difficulty of both methods and the topical ocular administration technique was evaluated. Results: Eye drop instillation was difficult or very difficult for $10 \%$ of the elderly with the device aid and for $36 \%$ without it $(p=0.0047)$. There were bottle tip touch onto the ocular tissues in $64 \%$ of patients who did not use Eyedrop ${ }^{\circledR}$ and $4 \%$ who used it ( $p$ $=0.000001)$. The greatest difficulty described in traditional instillation was to head properly the eye drop (32\%) and when the support device was used, it was to understand how to use it (4\%). Conclusion: Most elderly instills eye drops mistakenly, touching the tip of the bottle onto ocular tissues, which favors contamination. The facial support device increased security and facility in instillation.
\end{abstract}

Keywords: Administration, topical; Ophthalmic solutions/administration \& dosage; Lubricants; Eye/drug effects

\section{RESUMO}

Objetivo: Determinar o grau de dificuldade para instilação tópica ocular em idosos, com ou sem o auxílio de dispositivo de apoio facial, por meio de questionário. Observar qual método foi tecnicamente melhor para aplicação tópica ocular de gotas. Métodos: O estudo foi um ensaio clínico, controlado, randomizado e pareado, realizado em 50 pacientes idosos de setembro de 2015 a junho de 2016 na Policlínica Ronaldo Gazolla, Lapa-Rio de Janeiro. Um frasco de colírio Optive ${ }^{\circledR}$ foi acoplado ao dispositivo de apoio facial denominado Eyedrop ${ }^{\circledR}$. Cada participante instilou o colírio com ou sem o auxílio do dispositivo em cada um dos olhos, sendo que a seleção ocular foi feita aleatoriamente. Foi perguntado ao paciente questões pré-formuladas sobre a dificuldade de ambos os métodos e a técnica de administração tópica ocular foi avaliada. Resultados: A instilação de gotas foi considerada difícil ou muito difícil por $10 \%$ dos idosos com o auxílio do dispositivo e por 36\% sem o auxílio (p = 0,0047). Houve toque da ponta do colírio com os tecidos oculares em $64 \%$ dos pacientes que não usaram o Eyedrop ${ }^{\circledR}$ e em $4 \%$ dos que o utilizaram ( $\left.\mathrm{p}=0,000001\right)$. A maior dificuldade descrita na instilação tradicional foi acertar o olho com a gota (32\%) e com o dispositivo de apoio foi entender seu uso(4\%). Conclusão: A maioria dos idosos instila colírios erroneamente, tocando a ponta do frasco em tecidos oculares, o que favorece sua contaminação. O dispositivo de apoio facial tornou mais segura e fácil a instilação.

Descritores: Administração tópica; Soluções oftálmicas/administração \& dosagem; Lubrificantes; Olho/efeitos de drogas

\footnotetext{
1 Ophthalmology Service of Policlinica Ronaldo Gazolla, Universidade Estácio de Sá, Rio de Janeiro, RJ, Brazil.

2 Academic Course of Medicine, Universidade Estácio de Sá, Rio de Janeiro, RJ, Brazil.
}

The authors declare no conflicts of interests.

Received for publication 23/09/2016 - Accepted for publication 02/10/2016 


\section{INTRODUCTION}

$\mathbf{T}$ he instillation of drops is the main route of ocular administration used for the treatment of diseases of the anterior segment. The site of action of this route often hits different layers of the cornea, conjunctiva, sclera, iris and ciliary body. ${ }^{(1)}$

The correct use of eye drops need proper practice of fine motor movements and good vision. Many patients, especially the elderly, have difficulties due to reduced motor coordination and bad near sight without glasses. ${ }^{(2)}$

Recent studies have shown that many patients use eye drops incorrectly. Some of them touch tip of the bottle in the eye tissues, others dribble too many drops or miss the eye and spend the eye drops unnecessarily. Said actions can increase, respectively: bottle contamination, toxicity, and increased cost for treatment. ${ }^{(3-5)}$

In order to improve the techniques of using eye drops, several facial support devices were created. Among them we can mention: Opticare ${ }^{\circledR}$, Eyeot $^{\circledR}$, Xal-Ease $^{\circledR}$, Autodrop $^{\circledR}$, Autosqueeze $^{\circledast}$, Eyedrop ${ }^{\circledast}$, etc. ${ }^{(6-8)}$

Facial support devices can improve the application of eye drops to promote: manual support for administration, better positioning of the bottle in relation to the eye, and easier to squeeze the bottle or keep the eyelids open.(9)

After extensive research in digital databases like LILACS, PubMed, and Scielo we didin't find any studies on the perception and technical adequacy of self instillation of eye drops only in the elderly.

The present study aims to study the perception and technical adequacy of the elderly in relation to self instillation of eye drops with and without Eyedrop ${ }^{\circledR}$ facial support device.

\section{Methods}

The study was a controlled, randomized, paired clinical trial performed in 100 eyes of 50 elderly patients during the period from September to November, 2015 and from March to June, 2016 in the ophthalmology ambulatory of Policlínica Ronaldo Gazola. Policlínica is located in the neighborhood of Lapa, Rio de Janeiro, and is a health unit of the Medicine School of Universidade Estácio de Sá - RJ.

The study included only patients over 65 years old and who stated knowing how to instill eye drops in the eyes. Monocular patients with any cognitive difficulty which would prevent answering to the questions of the questionnaire were excluded, as well as presenting external eye disease or being under the influence of any medication that would alter ocular sensitivity.

In addition to bottles of eye lubricant solution (Optive $\left.{ }^{\circledR}\right)$, a facial support device called Eyedrop ${ }^{\circledR}$ was used in the research. The device is about $5 \mathrm{~cm}$ high and $2.5 \mathrm{~cm}$ long, and is made of vshaped transparent acrylic (Figure 1). It also has a central hole to fit the eye drop bottle allowing the instillation of drops into the eye with the facial support (Figure 2).

All patients qualified who attended at one shift (morning or afternoon) for examination or appointment were invited to take part in the study. The shifts were chosen according to the convenience of the authors: $50 \%$ of patients were attended in 2015, 54\% of patients were referred to CENTRO DE SAÚDE
ESCOLA LAPA - RJ, which is a Unit of Family Health of Rio de Janeiro. The other patients payed the treatment or had health insurance plans.

Before the ocular topical administration, one of the authors explained the use of facial support device according to the general use guide of the product.

Each participant received a bottle of lubricant eye drops $\left(\right.$ Optive $\left.^{\circledR}\right)$, and was requested to perform the self-instillation in one of the eyes. The eye was previously selected using a table of pseudorandom numbers of the program Excel ${ }^{\circledR}$. In the other eye, the participant was asked to apply the solution of another bottle of eye drops Optive ${ }^{\circledR}$ coupled to facial applicator Eyedrop ${ }^{\circledR}$. The whole process was observed by one of the authors.

A questionnaire was applied after the instillations (Annex) about the difficulties and technical adequacy of both methods. After data collection, they were inserted in the database of the program Epi Info $7^{\circledR}$, where descriptive statistics were performed. The inferential statistical tests were performed with calculators available at: "http://vassarstats.net". The "Wilcoxon paired rank" test was applied to the data obtained from questions 4 and 5 , the paired "Student $t$ test" to the result of questions 11 and 5, and the McNemar test was applied to the answers of questions 8 and 12,9 and 13,10 and 14 . Statistical significance was set at $\mathrm{p}$ (twotailed) $<0.05$.

The present research was submitted and approved by the Research Ethics Committee of Universidade Estácio de Sá (CAAE: 46034115.1.0000.5284 ). All participants signed an informed consent form.

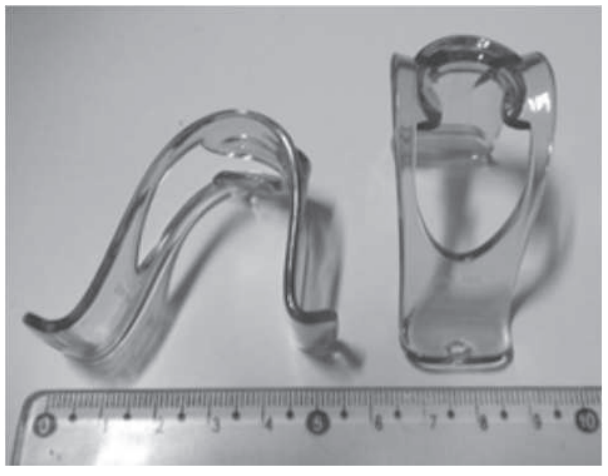

Figure 1: Facial support devices Eyedrop ${ }^{\circledast}$

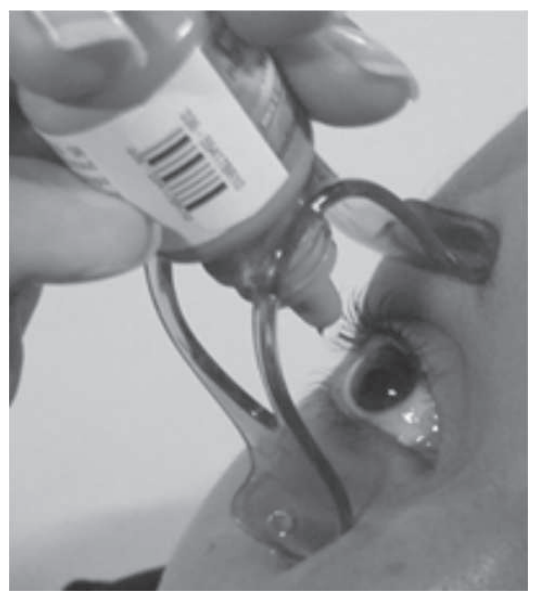

Figure 2: Instillation of drops with the facial support device 


\section{RESULTS}

The average age of the participants was 74.98 years, with standard deviation of 6.79 years. Seventy percent $(70 \%)$ were female.

Forty-eight percent ( $48 \%$ ) considered the instillation of drops easy or very easy, while seventy percent $(70 \%)$ ranked the same way the instillation of drops with the aid of the facial support device. On the other hand, $36 \%$ classified as difficult or very difficult the instillation of drops without the facial support device, and $10 \%$ with the facial support device (Table 1). The result was statistically significant to detect the difference in the groups studied ( $\mathrm{p}=0.0047)$.

\section{Table 1}

Degree of difficulty for instillation of drops of eye drops

\begin{tabular}{lcc}
\hline Degree of difficulty & Eye drops (\%) & Facial applicator (\%) \\
\hline Very easy & 8 & 30 \\
Easy & 40 & 40 \\
Neither easy nor difficult & 16 & 20 \\
Difficult & 34 & 8 \\
Very difficult & 2 & 2 \\
Total & $\mathbf{1 0 0}$ & $\mathbf{1 0 0}$ \\
\hline
\end{tabular}

Fifty percent $(50 \%)$ of the individuals claimed having some difficulty to instill drops, the most common being (48\%) hitting the eye. Eighteen percent said they had some difficulty to instill drops of eye drops with the Eyedrop ${ }^{\circledR}$, the most common (30\%) being positioning the device (Table 2).

Table 2

Difficulties described by respondents

\begin{tabular}{lcc}
\hline Type of difficulty & Eye drops & Facial applicator \\
\hline Hitting the eye & 16 & 1 \\
Need help to instill & 4 & 1 \\
Doesn't open the eye & 4 & 1 \\
Jitters & 2 & 1 \\
Need a mirror & 2 & 0 \\
Pull the eyelid & 1 & 0 \\
Coordinate movements & 1 & 0 \\
Shake the hand & 1 & 0 \\
Change the eye drops & 1 & 0 \\
Position the bottle & 1 & 0 \\
Position the device & 0 & 3 \\
Tilt the head back & 0 & 1 \\
Understand how to use the & & 2 \\
facial support device & 0 & $\mathbf{1 0}$ \\
Total & $\mathbf{3 3}$ & \\
\hline
\end{tabular}

The first drop reached the eyeball in $76 \%$ of patients who instilled eyedrop without the facial support device, and in $80 \%$ of individuals who did it with the device $(\mathrm{p}=0.58)$. The repetition of instillation occurred in $34 \%$ of individuals who used eye drops, and in $36 \%$ of those who used the device $(\mathrm{p}=1.0)$. There was no statistically significant difference regarding the number of times the first drop instilled hit the eye or the need to repeat the instillation.
The average number of drops instilled to the eye using the facial support was 1.51, and for the eyes that used eye drops was 1.37. There was no statistically significant difference between the groups $(\mathrm{p}=0.2899)$.

In $64 \%$ of individuals observed, the tip of the eye drop bottle without the device touched the eyelids or lashes of the patients; this also occurred in $4 \%$ of individuals who used the device. There was statistically significant difference regarding touching the tip of the bottle in the eye tissues $(p<0.000001)$.

No adverse effects have been observed.

\section{Discussion}

Portes et al. ${ }^{(4)}$ published a study about the perception of ocular topical application of eye drops using the facial support device different from the Eyedrop ${ }^{\circledR}$ in 2011. The authors noted that there was less touch of the tip of the bottle in eye tissues when using the device, but the individuals reported being easier to use the device. In the present work the greater ease with the use of the device occurred between the groups studied (Tables 1 and 2). One of the main explanations for the difference in the results is that in 2011 predominantly adults were studied, and in the present work the population was of elderly. It is known that the elderly presented over time a worsening of fine motor coordination, and therefore they are a group that can benefit the most from the facial support devices. ${ }^{(10)}$

Sakiyalak et al. ${ }^{(11)}$ conducted a prospective, cross-linked and randomized study comparing the proportion of successful self-instillation of eye drops in patients with glaucoma who used or not a facial support device. The device was named "Thai Eye Drop Guide" (patent 6555, Mahidol University, 9/2/ 2011). The authors found no significant difference in percentage of success when the patients were well instructed in the traditional technique of instillation and in the technique of using the device. The use of Eyedrop ${ }^{\circledR}$ in the current study did not bring improvement in accuracy of instillation as well, considering the number of droplets released or if the first droplet hit the ocular surface. Therefore, a greater sense of ease was translated into support and comfort in the positioning of the bottle, away from the eyelashes or eye tissues.

Junqueira et al. ${ }^{(7)}$ studied 32 adult individuals with glaucoma or healthy, and the efficacy and safety of the device Eyedrop ${ }^{\circledR}$. The ease to instill was considered greater in the eyes in which the device was used, especially when there was no prior experience on instillation of eyedrops. The use of the device did not result in hypotensive effect different from the traditional instillation. Despite the greater ease reported to instill drops using the Eyedrop ${ }^{\circledR}$, the authors consider that the results should be interpreted with limitations. The sample was small, despite having enough power to result in statistical significance of the results, and the introduction of a new device may cause bias in favor of the instrument, because a new equipment can produce greater commitment or expectation of the individual testing it. The limitations set out by Junqueira et al. can be considered for the current job.

Nordmann et al. ${ }^{(12)}$ published in 2009 a multicenter, prospective, randomized and cross-linked study with 211 individuals in France to assess the impact of the device XalEase $^{\circledR}$ in relation to the treatment of primary open-angle glaucoma with latanoprost or latanoprost and timolol. The 
authors observed that the use of the device reduced the need for someone to help the patient on instillation and decreased the problem of touching the tip of the bottle of eye drops into the eyes $(\mathrm{p}<0.001)$. Gomes et al. ${ }^{(8)}$ published a study in 2016 noting that the use of eye drops with the aid of Xal-Ease ${ }^{\circledR}$ decreased the touch of the bottle tip into the eyes of patients without experience in topical administration of eye drops, but there was increase in the number of drops instilled when the individuals used the device. In our study, we observed that the use of the Eyedrop ${ }^{\circledR}$ also reduced the touch of the tip of the bottle of eye drops into the eye tissues, and there was selfperception of greater ease for ocular topical application, in addition to reports of less difficulty in individuals who have used the device.

The facial support devices keep the bottle of eye drops away from the eyes to a predetermined distance which makes the touch of the tip of the bottle in the eye tissues and around the eyes more difficult. ${ }^{(4)}$ A large portion of individuals with and without experience in instilling eyedrops instills it wrongly, touching the bottle into the eyelids or eyes, which favors the contamination. ${ }^{(5)}$ The devices can help reduce this technical error.

There was a difference in the present research between the number of drops instilled between the eyes of those who used Eyedrop ${ }^{\circledR}$, as in the work of Gomes et al. ${ }^{(8)}$ Probably this is because all patients assessed were experienced in instilling eye drops and this ability helps using the facial support devices correctly initially.

It was found that for the device Eyedrop ${ }^{\circledR}$ to be used properly, it is necessary to have a greater extension of the neck than when instilling a drop. Such extension may not be possible for individuals with disorders of the cervical spine.

\section{Questionnaire - Perception of ocular self-instillation of drugs:}

Comparison of drops applied with and without facial support device

1. Number of medical record::

2. Initials of the name:

3. Age:

4. Regarding instillation of eye drops, you consider it:
1) Very easy ( )
2) Easy ( )
3) Not easy nor difficult ( )
4) Difficult ( )
5) Very difficult ( )

5. Regarding the use of the facial support device in open eye, you consider it:
1) Very easy ( )
2) Easy ( )
3) Not easy nor difficult ( )
4) Difficult ( )
5) Very difficult ( )

6. About the topical administration of eye drops, do you have any difficulty?

( ) Yes ( ) No.

If yes, which one(s)?

7. Regarding the instillation of drops with the device, do you have any difficulty?

( ) Yes ( ) No.

If yes, which one(s)?

Note:

In relation to the eye drops:

8. Did the drop instilled fall in the eye? ( ) Yes ( ) No.

9. Was it necessary to repeat instillation so that it fell in the eye?

$$
\text { ( ) Yes ( ) No }
$$

10. Did the tip of the bottle touch the eyelashes or the eyelid or the eye? ( ) Yes ( ) No.

11. How many drops were applied?

Regarding the use of the facial support device:

12. Did the drop instilled fall in the eye? ( ) Yes ( ) No.

13. Was it necessary to repeat instillation so that it fell in the eye?

( ) Yes ( ) No.

14. Did the tip of the bottle touch the eyelashes or the eyelid or the eye? ( ) Yes ( ) No

15. How many drops were applied? 


\section{CONCLUSION}

Self-instillation of drops of eye drops in the elderly was facilitated and safer with the use of the facial support device Eyedrop ${ }^{\circledR}$. Further studies are needed to verify if the ease observed is justified by the worse fine motor coordination of the elderly.

\section{ReFERENCES}

1. Gaudana R, Ananthula HK, Parenky A, Mitra AK. Ocular drug delivery. AAPS J. 2010;12(3):348-60.

2. Dietlein TS, Jordan JF, Lüke C, Schild A, Dinslage S, Krieglstein GK. Self-application of single-use eyedrop containers in an elderly population: comparisons with standard eyedrop bottle and with younger patients. Acta Ophthalmol. 2008;86(8):856-9.

3. Gupta R, Patil B, Shah BM, Bali SJ, Mishra SK, Dada T. Evaluating eye drop instillation technique in glaucoma patients. J Glaucoma. 2012;21(3):189-92.

4. Portes AJ, Silva MG, Viana M, Paredes AF, Rocha J. Percepção da administração tópica ocular de drogas: aplicador facial x gotas. Rev Bras Oftalmol. 2011;70(4):224-9.

5. Vaidergorn PG, Malta RF, Borges AS, Menezes MD, Trindade ES, Santiago JB. [Eye drop instillation technique in chronic glaucoma patients]. Arq Bras Oftalmol. 2003; 66(6):865-9. Portuguese.

6. Strungaru MH, Peck J, Compeau EC, Trope GE, Buys YM. Mirrorhat device as adrop delivery aid: a pilot study. Can J Ophthalmol. 2014;49(4):333-8
7. Junqueira DM, Lopes FS, de Souza FC, Dorairaj S, Prata TS. Evaluation of the efficacy and safety of a new device for eye drops instillation in patients with glaucoma. Clin Ophthalmol. 2015;9:367-71.

8. Gomes BF,Lordello M, Celli LF, Santhiago MR, Moraes HV. Comparison of eyedrop instillation technique with and without a delivery device in inexperienced patients. Eur J Ophthalmol. 2016; 27:0. doi: 10.5301/ejo.5000797.

9. International Glaucoma Association. Eye drops \& dispensing aids: a guide. Ashford: Kent; 2013.

10. Hoogendam YY, van der Lijn F, Vernooij MW, Hofman A, Niessen WJ, van der Lugt A, et al. Older age relates to worsening of fine motor skills: a population-based study of middle-aged and elderly persons. Front Aging Neurosci. 2014;6:259. doi: 10.3389/ fnagi.2014.00259.

11. Sakiyalak D, Maneephagaphun K, Metheetrairat A, Ruangvaravate N, Kitnarong N. The effect of the Thai "Eye Drop Guide" on success rate of eye drop self-instillation by glaucoma patients. Asian Biomed. 2014; 8 (2): 221-7.

12. Nordmann, JP, Bron A, Denis P, Rouland JF, Sellem ER, Renard JP. Xal-Ease: impact of an ocular hypotensive delivery device on ease of eyedrop administration, patient compliance, and satisfaction.Eur J Ophthalmol. 2009; 19(6): 949-56.

\section{Corresponding author:}

Arlindo José Freire Portes

E-mail: portes@uol.com.br 